Multidisciplinary

SCIENTIFIC JOURNAL OF

MARITIME RESEARCH

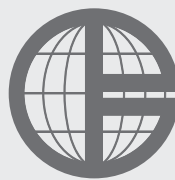

University of Rijeka

Faculty of Maritime

Studies Rijeka
Multidisciplinarni

znanstveni časopis

POMORSTVO

\title{
Competencies of logistics operators for optimisation the external costs within freight logistics solution
}

\author{
Tanja Poletan Jugović, Luka Vukić \\ University of Rijeka, Faculty of Maritime Studies Rijeka, Studentska 2, 51000 Rijeka, Croatia, e-mail: poletan@pfri.hr, lvukic@pfst.hr
}

\begin{abstract}
Maritime transport logistics outgrows the competence of classic freight forwarders deleting the boundaries among forwarders, brokers, and carriers and creates a new profession, logistics operator. They are now faced with the need for careful planning and coordination among multiple parties for shifting the freight logistics industry towards more sustainable goals. Significant need for political and operational respect of principles of sustainable development, and also external costs in this context, undertakes logistics operators to review their solutions in accordance with adequate knowledge, skills, and competencies. It is particularly important in forecasting the external costs which are not a central business interest. The above mentioned competencies are described focusing on subjects (issues and knowledges) through whom logistics operators should be trained. Moreover, logistics operators have a greater responsibility towards carriers but also an opportunity to reduce not only the cost of transportation but also the external costs within the logistic supply chain. In this paper calculation of external costs is, practically, shown in the example of towing in the port. The old education programs were compared with the new demands of the market. The substantial difference was evident in the subject of Marine Ecology whose content is becoming the central issue of sustainability of transport modalities. New competencies of logistics operators will become the relevant factor of sustainable development and competitiveness on the freight logistics market. That confirm the analysed current projects about present trends in the transport sector in which the green logistics including external costs become the important and binding element of cargo flow planning.
\end{abstract}

\section{ARTICLE INFO}

Review article

Received 2 November 2016

Accepted 2 December 2016

Key words:

Freight forwarder

Logistics operator

Competencies

External costs

Calculation

\section{Introduction}

Logistics has a central position in modern maritime transport systems and requires complex organization. Using modern technology it controls every step in freight movements. Logistics operators are responsible not only for organization and planning but also for coordination and integration of all the elements in transport and logistics chain. A broad range of skills and knowledge are expected from them today but what exactly it is not studied enough. Green logistics is a new challenge for logistics providers representing new field they should know. The significant need for political and operational respect of principles of sustainable development, and also external costs in this context, undertakes logistics operators to review their solutions in accordance with adequate knowledge, skills, and competencies. External costs have become the facts which change trans- port directions and modes, so logistic operators have to count on them. Logistic operators need the knowledge and skills for external costs calculation to become competent to perform their tasks successfully.

The goal of the research is to demonstrate that competencies of freight forwarders do not meet the requirements of the time. Given that the profession of freight forwarders expands to the profession of logistics operators, new challenges require the application of new knowledge, skills, and competencies. The old education programs will be compared with the new demands of the market and new trends and principles of sustainable development. The practical example of calculating the external costs of towing in the port will show the concrete application of the new competencies. There is also intention to point out and explain the increasingly important role of logistics operators in transport and logistics supply chain, especially in maritime transport. 


\section{Logistics and logistics operator competencies}

Logistics operator is the heart of transport logistics. In this part of paper the key features and necessary competencies will be analyzed.

\subsection{Key features of logistics operator term}

The term of logistics operator has evolved from the term of classical forwarder and logistics freight forwarder. Despite the unsettled terminology, it is clear that maritime transport logistics outgrows the competence of classic freight forwarders deleting the boundaries among forwarders, brokers, and carriers. The classic forwarders are transformed 'into numerous and more complex activities as well as the function of logistics forwarding' (Poletan Jugović and Jurčić, 2005) unifying often all three fields in the unique logistics service. They can be carriers, providers of special services such as "door to door", "just in time" or "outsourcing", can be included in transport and logistics supply chain, and have a significant part in determining of cargo flows. There is the need for the unique term. A wide range of competencies requires a term of general meaning accordingly. The term of logistics operator unifies the competencies of entire transport supply chain and does not limit professionals to be included at any level. Therefore, the term is grateful as a program of education.

Various other terms are also in use. They have developed according to new challenges in maritime business. Some of them will be shown in the next subsection. Actually, all of them have the meaning of logistics operator and are different according to the current context.

\subsection{Analysis of the necessary knowledge, skills, and competencies of the logistics operator}

Competencies of maritime logistics professionals or executives (operators) are business related (maritime specific), logistics related (maritime specific, port specific) and management related (maritime specific) (Thai and
Yeo, 2012). Understanding of project management, project financing, commercial and transport law, as well as an ability to optimize the supply chain network, are obligate. The useful degree subjects are shown in Table 1.

Although it is difficult to compare programs without knowing the contents of individual items as well as programs of various degrees of education, it is quite clear that these are programs that serve education of freight forwarders in the full sense of the term. As will be seen in Table 2., the competencies required for forwarding cargo outgrow the training programs. Experts arising from such programs do not count with the concepts of green logistics, external costs, and sustainability. Indeed, one can say that these programs have become rare because the programs are replaced by programs of supply chain management, business administration management, and logistics in response to transformations in the business process of transportation (Colorado Technical, 2016). The development of environmental awareness changes slowly the transport policy which leads to the transformation of freight forwarders profession in the more complex logistics operators. Environmental factors (in maritime transport) are forcing logistics operators to take into account not only the logistics costs but also the external costs of transport affecting the flow of goods.

There is also the need for new competencies from crossfunctional areas (Thai and Yeo, 2012). Forwarding and logistic service specialists work in freight forwarding and logistics companies (Timocom, 2016). They are familiar with freight costs, port charges, fees, best modes and cost of transportation, documentation and so on (Bryant, 2015).

The maritime logistics value is measured by the following six indicators: business cost, lead time, on time, responsiveness, flexibility, and reliability (Lee and Song, 2015). The educational programs must respond to the new challenges of the business positioning. Some freight forwarders spread their job becoming the carriers as Non Vessel Operating Common Carrier (NVOCC) and NonVessel Multi-Modal Transport Operator (NV-MTO). Their responsibility is even greater because they are liable for the entire transport (multimodal) as well as for the sub-

Table 1 Subjects necessary in education of freight forwarders at three different universities in USA and UK

\begin{tabular}{|c|c|c|}
\hline $\begin{array}{l}\text { Subjects* } \\
\text { (graduate) }\end{array}$ & $\begin{array}{c}\text { Subjects** } \\
\text { (undergraduate) }\end{array}$ & $\begin{array}{c}\text { Subjects*** } \\
\text { (undergraduate) }\end{array}$ \\
\hline Accounting/finance & Finance & Basics of International Trade \\
\hline Business with languages & Statistics & Import Air Operation, Documentation and Process \\
\hline Economics & Business law & Export Ocean and Air Freight Forwarding and Export Declaration \\
\hline \multirow[t]{3}{*}{ Supply chain management } & & Government Agency and Association \\
\hline & & Job Application in the field of logistics \\
\hline & & Freight Forwarding Software Practice \\
\hline
\end{tabular}

Source: *PROSPECTS, 2014; **Colorado Technical, 2016; ***Kenvic Training, 2016 
Table 2. General competencies of freight forwarder by CENTRAL project (Kovács and Pató, 2014, modified)

\begin{tabular}{|c|c|c|}
\hline Knowledge & Skills & Competence \\
\hline $\begin{array}{l}\text { - Cost-calculation } \\
\text { - The logistics market: transport modes, services and actors } \\
\text { - Contracts and main aspects of related regulation } \\
\text { - INCOTERMS -interpreting trade terms } \\
\text { - Quality assurance } \\
\text { - Goods, packaging, warehousing technology, logistics controlling } \\
\text { - English language } \\
\text { - Relevant documentation } \\
\text { - The range of services offered by their company and its structure } \\
\text { and business } \\
\text { Specific areas of: } \\
\text { - Traffic geography } \\
\text { - Supply-chain management and logistics } \\
\text { - International trade } \\
\text { - Legal aspects of business transactions } \\
\text { - Finance (bank-related operations) }\end{array}$ & $\begin{array}{l}\text { - Use the company's ICT systems, } \\
\text { standard software and workplace- } \\
\text { specific software } \\
\text { - Assist in implementation of QA } \\
\text { methods } \\
\text { - Correspond and communicate } \\
\text { with business partners in } \\
\text { English, process English language } \\
\text { documents } \\
\text { - Consider cost-and time } \\
\text { effectiveness when planning and } \\
\text { organizing his/her work } \\
\text { - Apply research methods }\end{array}$ & $\begin{array}{l}\text { - Make well-informed decisions } \\
\text { swiftly } \\
\text { - Organize his / her work and the } \\
\text { work of others in an efficient and } \\
\text { effective way } \\
\text { - Communicate effectively with } \\
\text { customers and other departments } \\
\text { - Coordinate work with the rest of } \\
\text { the team and other departments } \\
\text { - Act as an "entrepreneur" when } \\
\text { conceiving new business plans and } \\
\text { networking outside the company }\end{array}$ \\
\hline
\end{tabular}

contractors (Singapore Registry, 2013). They can become so-called 'one stop shop' logistic service provider (LSP) offering complete logistics as outsourcing service (Folinas, 2013). They can operate domestically, internationally or globally (Pidgeon, 2016). With adequate competencies, such companies use technologies to allow better management of physical variables in an increasingly global market (Kreowski et al., 2009).

\section{Green logistics and external costs in function of optimisation and revalorisation of the freight logistics industry}

In last 20 years, the environmental impacts of freight transportation came into public focus and under the name of green logistics has the important role in the market of transport services. It is involved in all degrees of transport and logistics chain including the material handling, packaging and waste management.
Green logistics promotes three guiding principles: sustainability, mobility, and accessibility. These, in turn, support more specific goals such as environmental friendliness and energy conservation.

The logistics procedures for reducing environmental externalities are not always accepted by business stakeholders as well as by logistics operators. Indeed, there are good arguments for them called green logistics paradoxes (Rodrigue et al., 2001). Improvements in transport business reducing internal costs often lead to increasing of external costs (Table 3).

Rosen (2002) defines the externalities as follows: "When the activity of one entity (a person or a firm) directly affects the welfare of another in a way that is outside the market mechanism, that effect is called an externality." The cost of damage from such activities that is not covered by the entity that has done it, represents a social cost and is called the external cost.

Usually, logistics operators were not forced to pay external costs so far, and they did not have to include these

Table 3 The Paradoxes of Green Logistics (Rodrigue et al., 2001, modified)

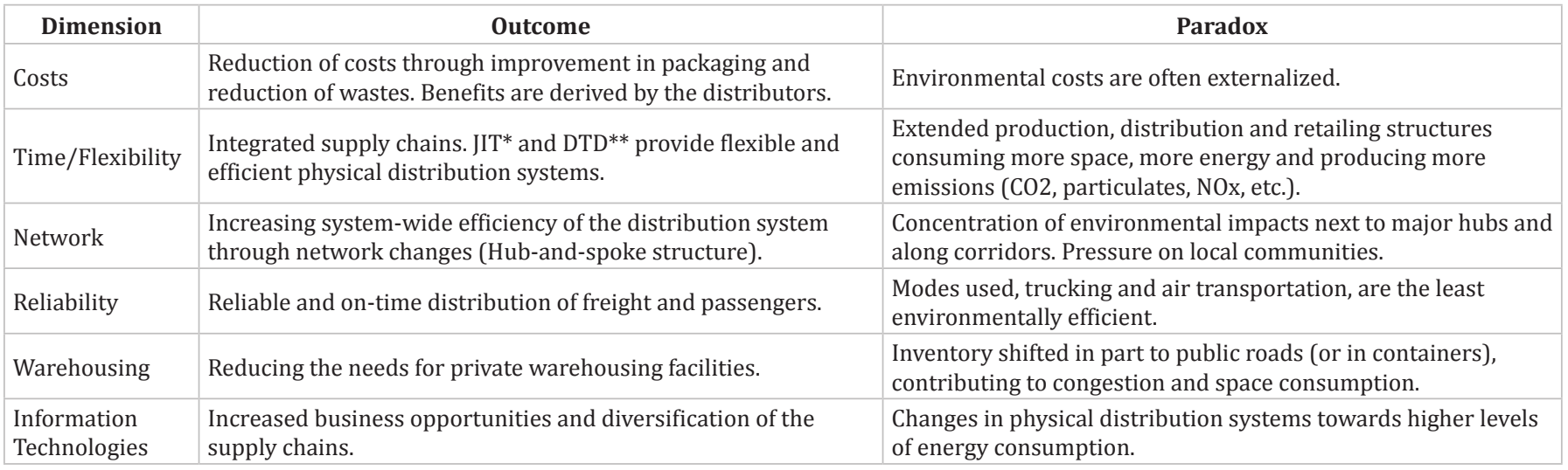

Notes: *Just in time; **Door to door 
costs in their service prices to their clients or for themselves. They are now faced with the need for careful planning and coordination among multiple parties for shifting the freight logistics industry towards more sustainable goals (Sathaye et al., 2006).

In order to reduce the external costs and remain competitive at the same time, they need new competencies, the knowledge, and skills for calculation of external costs. It is well known the rule for seaports but also generally, in economics is accepted that the companies are more successful if they are developed not only internally but also externally at the same time (Normann and Ramírez, 1994). It is evident in the example of tariffs for the use of port's infrastructure. The production is optimal where tariffs are optimal, and they are optimal if they are just at the social marginal cost level (Meersman et al., 2016). It is another reason to become competent in the external cost calculation.

Transport is far from being sustainable producing noise and air pollution, and climate change by greenhouse gas emissions. Except for the environmental impacts, there is accidents and congestion as the externalities of transportation resulting in external costs. The logistics operators are faced with challenges to find the directions and modes of transportation to reduce the external costs as much as possible. In the supply chain network, they are real masters and have opportunity, duty and responsibility to satisfy both production and consumption (McGlade, 2008). Commercials as Green Cargo in Sweden Railways using environmentally labelled electricity are welcome in public and also in business (Lammgård, 2007). As can be seen above, Kovacs and Pato (2014) elaborated the profile of logistic operator listing a number of competencies they need. The field of transportation influence on environment and society and logistics operator competencies about it was not covered. It shows that awareness of this influence has not yet become the everyday way of thinking. There are a number of projects granted by the EU promoting the green logistics and the transport sector. The MER project deals with the sustainability of freight transport. In the framework of the ECOMARK project, software for routes optimization was developed. The KASSETTS project resulted with software for load optimization (Stacchini, 2014). The SWIFTLY Green project finished in 2015, discovered 'what measures should choose by transport companies and decision-makers to reduce emissions of greenhouse gasses without raising transport costs' accepted by the COP 21 (Swiftly Green, 2016). The ENERPLAN project deals with 'green' optimization for the containerized transportation sector, reducing energy consumption looking for best solutions for logistic operators in making decision (Pisinger, 2009). According to European Green Logistics Strategies, the SELIS project continues work on optimization of transport logistics including freight forwarders sector (SELIS, 2016). All projects confirm the present trends in the transport sector in which the green logistics including external costs become the facts that must be seriously considered.

\section{Making decision in transport and logistics chain according principles of green logistics}

Freight transport as a part of the production logistics has prices representing the cost for producers, shippers, and forwarders (OECD, 2002). All interested parties in logistics chain have an opportunity for making decisions trying to cut costs as much as possible.

Usually, great companies have own logistics service and are not especially interested in covering external costs (López-Navarro, 2014). If sustainability in freight traffic is not under state control, such companies are not particularly interested in intermodal transport as well as in green logistics in general (Bretzke and Barkawi, 2013). Contrary, logistics operators, working for middle and small firms (Feo et al., 2011), are interested in reducing external costs directly and indirectly. Looking for the best mode of transport, including intermodal or multimodal, and promoting a sustainable or environmentally more acceptable mode of transport, they create a positive public opinion. It is their commercial interest to be more competitive in the market of traffic services. Directly, they are interested not to bear external costs as a third party especially if they are not a carrier and do not produce externalities by themselves (Talley, 2009). Decreasing their prices by choosing different execution modes and by smart subcontracting they reduce own total costs, and indirectly also the external costs (Krajewska and Kopfer, 2006).

Comparisons of internal and external costs as well as turning fixed costs into variable costs are the basic principles of making outsourcing decision (IHS Markit, 2016). Although these principles in making the decision seem simple and normal, in the business world there is a thin line between them. The transport logistics chain network is a sensitive system where, e.g., a little delay at one step can result in a big delay at the end. It needs permanent control and harmonization of all the steps during the entire time of transportation. It is the main reason for great companies which do not use the outsourcing service to abandon of, e.g., the intermodal transport. It is also the opportunity for the logistics operators which can offer better solutions regarding delivery time and sometimes, some environmental benefits (López-Navarro, 2014). It is clear that competencies in this business have a key role in getting best results. It is particularly important for external costs which are not a central business interest.

\section{Logistics operator and external costs calculation}

The competencies of logistics operator, based on the principles of green logistics, define the factors of sustainability of transport modalities, such as transport effect (or transport reach) and infrastructure and external 
costs (Bureau, 2005). In this paper will be described the competencies in the context of external costs focusing on subjects through which they should be trained. The calculation of external costs will be practically shown in the example of towing in the port.

\subsection{External cost calculation as a competency of logistics operator}

López-Navarro (2014) wonders "how decision makers can compare the environmental impacts between transport modes?" Increasing transportation, except positive effects in economics, has some negative effects manifesting through external costs of damages done by emissions, noise, congestion and accidents in transport.

As the economic parameters of transportation benefits are easy measured, so the values of external costs are not. If there is a thesis that intermodal transport reduces the external costs, there are also the evidence that it not always the case. Moreover, there is a need for estimation or calculation of external costs for each direction in getting relevant data. As road transport produces the majority of external costs, the most have done for road vehicles to lower them. Contrary, there are not results of such quality in maritime transport and today is not easy to say anymore that the maritime transport is environmentally most accepted.

Logistics operators must adapt their services due to externalities and external costs in the sector of transport but also work on their competencies in this field. On first sight, the necessary knowledge and skills are probably slightly different than it could be expected. Principally, the external costs should be calculated. It will be described in the example of towing the ships in the port.

\subsection{Subjects needed for acquiring the competency for external costs calculation}

There are various modes how the external cost can be calculated. Although there is the IT external cost calculator available today, e.g., developed recently for the Marco Polo freight transport project (Brons and Christidis, 2011), the logistic operator would have to know the basic principles of calculation in order to understand what he really works. When it comes to maritime transportation, the environmental impacts predominate in total external costs, while the congestion and accidents are negligible. The same is true for noise with the difference that is real but minimally participates in total damage. External costs in maritime transport appear in sailing and while in port. The logistic operator should learn it through subjects as ship management and port economics.

The emissions participate with over $70 \%$ of all environmental impacts and are enough to calculate them to get the real values of external costs. Among various pollutants $\mathrm{CO}_{2}, \mathrm{SOx}, \mathrm{NOx}$, and $\mathrm{PM}_{25}$ are the most important representing the majority of external costs. In the context of external costs, the importance of other pollutants ( $\mathrm{CO}$, VOC, $\mathrm{CH}_{4}$, heavy metals, etc.) can be ignored. All of them are the products of combustion of fuel oil and their quantity depends on the type of oil. The types of oil are differentiated mainly according to sulphur share in them. Less amount of sulphur in oil leads to fewer pollutants in the air. It is the field of chemistry.

Different ships produce different amounts of pollutants. Except to the fuel oil type, the ship engine power is decisive in the external cost calculation. It is also important the level of engine loading or revolving per minute (rpm). There are also the engine systems for reducing the emissions, especially in NOx emission. While at berth the auxiliary engine keeps working so it is necessary to know its characteristics. This knowledge is available in mechanics and engine basics.

The transportation environmental damages reflect on society mainly by threatening the health. The costs of pollutants are really the health costs of people who suffered as well as the costs of absence from work and community. There is also the impact on agriculture and industry, nature and atmosphere including climate changes. It should learn through subjects as ecology or green logistics.

The basics of navigation, docking, organization of work on the ship and in port, conduct, and accountability, and in particular the handling of cargo, loading, and unloading while in port, and energy spent for all these activities are the elements which affect the level of external costs. Knowledge of maritime law and the rules in some ports could be decisive in the choice of the best, fastest and safest forms of transportation. Thus, the logistics operators need the knowledge on navigation and port technologies.

Passing the way from fiction to reality, the external costs become the important and decisive factors of modern transport. In the beginning, sporadic internalization of external costs is gradually becoming bigger and bigger significantly increasing the total costs of transport. The logistic forwarders have responsibility and a challenge to find the best way of transportation counting on external costs at every step of logistic chain network including the intermodal transport. It means the acquisition of necessary knowledge of all modes of transportation.

An indicative list of courses required for the acquisition of knowledge about the external costs of the maritime transport shows Table 4.

Table 4 Subjects necessary for calculation external costs in maritime transport
Ship management
Port economics
Marine science - Chemistry
Technical Mechanics - Ship Engines
Marine Ecology - Green Logistics
Maritime Law
Port Technologies
Navigation 
Comparing the programs listed in Table 1. with the programs listed in Table 4. it is evident the substantial difference in paragraph Marine Ecology-Green Logistics (except special maritime items) whose content is becoming the central issue of sustainability of transport modalities. Of course, differences are present also in the curricula of the same or related items that should be adapted to the new challenges, in this case, for the calculation of external costs.

\subsection{External cost calculation in the example of towing in the port of Brindisi}

Towing is an often required procedure in the port. Sometimes, cannot be avoided due to port rules. It is a source of pollution that is often forgotten but other than towing cost, the size of external costs can be crucial for logistics operators when choosing a destination port.

According to rules of the port of Brindisi, ships longer than $100 \mathrm{~m}$ as well as shorter ships which are not equipped with the bow thruster necessarily use towing service in arriving. The ships with dangerous cargo must be towed by 1-4 tugboats, according to their capacity, in both directions (Ordinanza n. 107/2015). The costs of this service, as well as its external costs, have to be added to the total cost of transport. Mainly, it should count on the use of a tugboat during entrance to the port and the mooring procedure. The port of Brindisi is a bay deep $3.1 \mathrm{Nm}$, but the distance from the entrance to the place of berth is $1.5 \mathrm{Nm}$ in average, mainly in the outer and middle part of port (Docks list, 2016). Sometimes, they are necessary also at departing, especially for bigger ships. There are seven tugboats in service and the type of Tenax series is used in the example (Tow Service, 2016). It is powered by two diesel engines of $2400 \mathrm{~kW}$ at $1000 \mathrm{rpm}$ each (medium speed engine). It needs about 20 minutes of work per a call (Marine Traffic, 31.10.2016). For towing winches, there are also two $245 \mathrm{~kW}$ power engines which are not included in the calculation because usually they are not used in port (Technical specifications, 2011). The engines use marine diesel oil (MDO).

Now, all the pieces of information needed to calculate the emissions of $\mathrm{CO}_{2}, \mathrm{SOx}, \mathrm{NOx}$ and $\mathrm{PM}_{2.5}$ are available. The formulas and technical data necessary for the calculation can be found in the literature.

According to Hulskotte et al. (2014) diesel oil consumption for medium speed engines is $175-200 \mathrm{~g} / \mathrm{kW} / \mathrm{h}$. A load of the engine is estimated to $75 \%$ so the fuel consumption is minimal. The uptime per a call is about 30 minutes (always at arriving, 20 minutes and sometimes at departing, added 10 minutes).

The consumption per a call is $0.175 \times 2 \times 2400 \times 0.5=$ $420 \mathrm{~kg}$.

According to Trozzi and Vaccaro (1998) medium speed diesel engines powered by MDO release as follows: 57 $\mathrm{g} / \mathrm{kg}$ of NOx, $3200 \mathrm{~g} / \mathrm{kg}$ of $\mathrm{CO}_{2}, 20 \mathrm{~g} / \mathrm{kg}$ of SOx and $1.2 \mathrm{~g} / \mathrm{kg}$ of PM. Due to various improvements in the engine, there is a correction factor for each item (especially for NOx emission) but it is not important for the example.

Total emission amounts: $23.94 \mathrm{~kg}$ of NOx, $1344 \mathrm{~kg}$ of $\mathrm{CO}_{2}, 8.4 \mathrm{~kg}$ of SOx and $0.5 \mathrm{~kg}$ of PM.

These values are multiplied by the current price of pollutants.

In different countries external costs for the same damage are different. They are also different due to an area where appear: rural, urban or at the sea (unpopulated area) (Holland and Watkins). The costs also depend on government policy and regional and local communities' rules. Respecting all reasons it is necessary to take over the values (costs) of emission damage published for certain country (region) and really, it is their damage. In the city of Brindisi live about 100,000 people. However, it should be noted that variations can be extreme so the value of $\mathrm{PM}_{2.5}$ may vary in an urban area from 18,200 (Ballini, 2013 ) to $317,000 € / \mathrm{kg}$ (Litman, 2015). The same goes for the price of a ton of $\mathrm{CO}_{2}$.

The external costs of pollutants are taken over from Holland and Watkiss (2015) specifically for urban area in Italy as follows (in $€ / \mathrm{kg}$ ): $6 € / \mathrm{kg}$ of SOx, $4.2 € / \mathrm{kg}$ of NOx, $33 € / \mathrm{kg}$ of $\mathrm{PM}_{2.5}$. According to TU Delft, (2012), the average and real cost of $\mathrm{CO} 2$ is $135 € / \mathrm{t}$.

The results show Table 5 .

The final calculation shows the following results: a cost of NOx was $100.55 €$, SOx $50.4 €, \mathrm{PM}_{2.5} 16.5 €$ and $\mathrm{CO}_{2}$ $181.44 €$. Total sum is $348.89 €$. If a total of greenhouses pollution is $1 / 3$ of overall pollution (TRT, 2007) then should add $174.89 €$ to get a total of $523.78 €$. Since all other pollutants were ignored for the reasons already discussed the external costs of towing in the port of Brindisi are at least $523.78 € /$ tugboat/call.

It needs to add the cost of towing to the cost of transportation. In the port of Brindisi, the cost of towing for a ship of the size of 20,000 GT is around € 3,000 (Ordinanza n. 108/2015). Logistics operator can speculate with the destination place depending on the port service costs in order to be more competitive in the market of transport services. Unlike to external costs of transport, external

Table 5 External costs calculation of towing in the port of Brindisi ( $€ /$ call)

\begin{tabular}{|l|c|c|c|c|c|}
\hline & NOx & SOx & PM $_{2.5}$ & CO $_{2}$ & Total (€) \\
\hline Emission factors (g/kg) & 57 & 20 & 1.2 & 3200 \\
Total emission (kg) & 23.94 & 8.4 & 0.5 & 1344 & 0.135 \\
Costs of pollutants (€) $\mathrm{kg}$ ) & 4.2 & 6 & 33 & 181.44 & 348.89 \\
Costs of emission (€) & 100.55 & 50.40 & 16.50 & 174.89 \\
Greenhouses pollution (€) & & & & & 523.78 \\
\hline Total $(€)$ & & & & \\
\hline
\end{tabular}


costs of towing are seldom mentioned. These costs are internalized through the cost of towing or not internalized at all. There are trend and principle that the damage pays the one who had done it'. It is only a matter of time when the carrier will have to count on external costs. Logistics operators with their competencies will then be able to operate on a different level and compete with the cost of transportation due to the destination depending on the external costs. Affecting the flow of goods logistics operators strengthen their role in logistics supply chain.

\section{Conclusion}

Green logistics has become a topic that cannot be ignored. External costs are real costs. Training programs for freight forwarders cannot answer to the requirements of the time. A strong development of logistics in the transport sector, ecological awareness as well as transport policies in accordance with the principles of sustainability expand their interests, duties and possibilities creating a new more complex profession.

Logistics operators have a greater responsibility towards the carriers, but also an opportunity to reduce not only the cost of transportation but also the external costs within the logistic supply chain. For this purpose, they need new competencies requiring new knowledge and skills to be able to calculate the external costs.

The case of external costs calculation of towing in the port shows exactly the competencies needed in maritime transport. Marine Ecology has a central position in education for necessary competencies. It also presents the respectable cost of towing and the high part of the external costs. Soon, it could become the point of competition. The ports with lower external costs will be cheaper for shippers. It would be an opportunity for logistics operators who would not have to be forced to include external costs in the account but contrary, it would be their tool of sustainable transportation and advantage in the market competition. With competencies in green logistics, the logistics operators would be able to influence strongly on flows of goods.

\section{References}

[1] Ballini, F.: Air Pollution from Ships in Danish Harbours: Feasibility Studyof Cold-ironing Technology in Copenhagen, Dissertation, Department of Naval, Electrical, Electronic and Telecommunication Engineering, University of Genoa, Italy, 2013.

[2] Bretzke, W.R., Barkawi, K.: Sustainable Logistics: Responses to a Global Challenge, Springer, pp. 1-84, Berlin, Heidelberg, 2013. doi: 10.1007/978-3-642-34375-9_1.

[3] Brons, M., Christidis, P.: External cost calculator for Marco Polo freight transport project, European Commission Luxembourg: Publications Office of the European Union (C) European Union, JRC Scientific and Technical Reports, 2011.

[4] Bryant, T.: How to Become a Freight Forwarder, Cerasis, 2015, online: http://cerasis.com/2015/06/29/how-to-become-a-freight-forwarder/ (30.10.2016).
[5] Bureau Voorlichting Binnenvaart, The criteria for determining the sustainability of transport modalities, The Power of Inland Navigation; The social relevance of freight transport and inland shipping 2004-2005, Rotterdam, The Netherlands.

[6] Colorado Technical University, 2016, online: http://study. com/directory/school/Colorado_Technical_University.html (06.10.2016.)

[7] Docks list, Porto di Brindisi, 2016, online: http:// www.porto.br.it/bpi/index.php\%3Foption\%3 Dcom_ content\%26view \%3Darticle\%26id\%3D14\%26Itemid\%3D 297\%26lang\%3Den (4.10.2016).

[8] Feo, M., Espino, R., García, L.: An stated preference analysis of Spain freight forwarders modal choice on the south-west Europe motorway of the sea, Transport Policy, Pergamon, Vol. 18, No. 1, pp. 60-67, 2011.

[9] Folinas, D.: Outsourcing Management for Supply Chain Operations and Logistics Service, IGI Global Disseminator of Knowledge, Hershey, 2013, online: http://www.igi-global. com/book/outsourcing-management-supply-chain-operations/64900 (30.10.2016).

[10] Holland, M., Watkiss, P.: Estimates of the marginal external costs of air pollution in Europe, Created for European Commission DG Environment by Netcen, 2015, online: http:// ec.europa.eu/environment/enveco/air/pdf/betaec02a.pdf.

[11] Hulskotte, J.H.J., Wester, B., Snijder, A.M.: International survey of fuel consumption of seagoing ships at berth, Work package 5, Clean North Sea Shipping, Norway, 2014.

[12] IHS Markit, JOC.COM, Shippers turn to forwarders for downturn 're-tuning', 2016, online: http://www.joc.com/ shippers-turn-forwarders-downturn-\%E2\%80\%98retuning\%E2\%80\%99_20100303.html (30.10.2016).

[13] Kenvic Training, New York, 2016, online: http://www. kenvictraining.com/international_freight_forwarding.php (06.10.2016)

[14] Kovács, Z., Pató, B.: Jobs and Competency Requirements in Supply Chains, Procedia - Social and Behavioural Sciences, Elsavier, Vol. 109, pp. 83-91, 2014, doi: 10.1016/j.sbspro.2013.12.424.

[15] Krajewska. M., Kopfer, H.: Profit sharing approaches for freight forwarders: An overview, In: Proceedings of the $5^{\text {th }}$ International Conference on Modern Trends in Logistics, pp. 157-161, St. Petersburg, Russia, 2006.

[16] Kreowski, H.J., Reiter, B.S., Thoben, K.D.: Dynamics in Logistics: Second International Conference, LDIC 2009, Springer Science \& Business, Bremen, Germany, 2009, doi: 10.1007/978-3-642-11996-5.

[17] Lammgård, C.: Environmental Perspectives on Marketing of Freight Transports, The Intermodal Road-Rail Case, BAS Publishing, Göteborg, 2007.

[18] Lee, E.S., Song, D.W.: Maritime Logistics Value in Knowledge Management, Routledge, London-New York, 2015.

[19] Litman, T.A.: Transportation Cost and Benefit Analysis II Air Pollution Costs, Victoria Transport Policy Institute, Victoria BC, Canada, 2015. online: www.vtpi.org/tca/tca0510. pdf (5.10.2016).

[20] López-Navarro, M.A.: Environmental Factors and Intermodal Freight Transportation: Analysis of the Decision Bases in the Case of Spanish Motorways of the Sea, Sustainability, Vol. 6, No. 3, pp. 1544-1566, 2014, doi:10.3390/ su6031544. 
[21] Marine Traffic, TENAX vessel: arrivals \& departures, 2016, online: http://www.marinetraffic.com/it/ais/index/port_moves/all/shipid:280860/mmsi:247294900/ shipname:TENAX (31.10.2016).

[22] McGlade, J.: Internalisation of external costs and greening transport, CLECAT Freight Forwarders' Conference, $50^{\text {th }}$ Anniversary, European Environment Agency Brussels, 2008.

[23] Meersman, H., Monteiro, F., Pauwels, T., Van de Voorde, E., Vanelslander, T.: Marginal Cost Pricing in Sea Ports: How to Model and Assess Differences Between Ports?, European Transport Conference, Book of abstracts, Association for European Transport, Barcelona, 2016.

[24] Normann, R., Ramírez, R., Den nya affärslogiken, Kristianstad: Liber-Hermods, Malmo, 1994.

[25] OECD, International Symposium on Theory and Practice in Transport Economics Key Issues for Transport beyond $2000,15^{\text {th }}$ International Symposium on Theory and Practice in Transport Economics, Thessaloniki, OECD Publishing, Greece, 2002.

[26] Ordinanza n. 107/2015, Regolamento locale di rimorchio nel porto e nella rada di Brindisi, Capitaneria di Porto di Brindisi, Ministero delle Infrastrutture e dei Transporti della Repubblica Italiana.

[27] Ordinanza n. 108/2015, Tariffe per il servizio di rimorchio nel porto di Brindisi, Capitaneria di Porto di Brindisi, Ministero delle Infrastrutture e dei Transporti della Repubblica Italiana.

[28] Pidgeon, C.: A Study Guide for the Operator Certificate of Professional Competence (CPC) in Road Freight, Kogan Page Publishers, 2016.

[29] Pisinger, D., ENERPLAN, Green Logistic Solutions, DTU Management, Technical University of Denmark, 2009, online: http://ercim-news.ercim.eu/en79/special/enerplangreen-logistic-solutions.

[30] Poletan Jugović, T., Jurčić, J: Logistics forwarder Operator as Perspective of the Classic Forwarder, Pomorski zbornik Journal of Maritime \& Transportation Sciences, Association for Research and Development of Maritime Industries Vol. 43, No. 1, pp. 151-163, Rijeka, 2005.

[31] PROSPECTS, Manchester, UK, 2014, online: https:// www.prospects.ac.uk/job-profiles/freight-forwarder (30.10.2016).

[32] Rodrigue, J.P., Slack, B., Comtois, C.: Green Logistics, In: Brewer, A.M., Button, K.J., Hensher, D.A.(eds), The Handbook of Logistics and Supply-Chain Management, Handbooks in Transport \#2, London: Pergamon/Elsevier, pp. 339-351, New York, 2001.

[33] Rosen, H.S.: Public Finance: Essay for the Encyclopedia of Public Choice, Princeton University, CEPS Working Paper No. 80, Princeton, USA, 2002.

[34] Sathaye, N., Li, Y., Horvath, A., Madanat, S.: The Environmental Impacts of Logistics Systems and Options for Mitigation, UC Berkeley Center for Future Urban Transport, Institute of Transportation Studies, University of California, 2006.

[35] SELIS, Towards a Shared European Logistics Intelligent Information Space, EU, 2016, online: http://www.selisproject. eu/Demonstration-and-Use.
[36] Singapore registry of accredited multimodal transport operators, International Freight Forwarding Committee Singapore Freight Forwarders Association, 2013, online: http://sla.org.sg/documents/10181/15857/ Multimodal+Transport+Operators/daab0205-e1e0-4bbb8b35-f358b2189119?version=1.0 (30.10.2016).

[37] Stacchini, V.: Promoting Green Logistics and Mobility Management, MER Project, Bologna, Italy, 2014, online: http://www.merproject.eu/mediawiki/index.php/2.6_ Promoting_Green_Logistics_and_Mobility_Management (05.10.2016).

[38] SWIFTLY Green, EU project for greening of transports, Gothenburg, Sweden, 2016, online: http://www.swiftlygreen.eu/en.

[39] Talley, W.K.: Port Economics, London-New York, Routledge, 2009.

[40] Technical specification of tug "Anna Cosentino", 2011, online: http://lnx.eurecoservizi.com/eureco/images/ eureco/PDF/st_anna\%20cosentino_rev1.pdf (4.11.2016).

[41] Thai, V.V., Yeo, G.T.: Formulating the Competency Framework for Maritime Logistics Professionals, Proceedings of the International Forum on Shipping, Ports and Airports (IFSPA) 2012: Transport Logistics for Sustainable Growth at a New Level, Hong Kong , China, 2012, online: http://www.icms.polyu.edu...gs $\% 20$ of $\% 20$ IFSPA $\% 20$ 2012.pdf (6.10.2016).

[42] TimoCom Soft- und Hardware GmbH, Freight forwarding and logistic services specialist / freight forwarder, 2016, online: https://www.timocom.co.uk/?lexicon $=1305221124487975 \% 7$ C Freight $\% 20$ forwarding $\% 20$ and $\% 20 \operatorname{logistic} \% 20$ services $\% 20$ specialist $\% 20 / \% 20$ freight $\% 20$ forwarder $\% 7$ CThe $\% 20$ transport $\% 20$ lexicon (30.10.2016).

[43] Tow Service, Port of Brindisi, 2016, online: http://www. porto.br.it/bpi/index.php?option=com_content\&view=arti cle\&id=3005\&Itemid=669\&lang=en (4.10.2016).

[44] Trozzi, C., Vaccaro, R.: Methodologies for estimating air pollutant emissions from ships, Techne report MEET RF98, 1998, online: http://www.inrets.fr/infos/cost319/ MEETdeliverable19.pdf.

[45] TRT - Trasporti e Territorio srl., External cost of maritime transport. Rapporto richiesto da European Parliament Committee on Transport and Tourism, Policy Department for Structural and Cohesion Policies, IP/B/TRAN/ FWC/2006-156/Lot4/C1-SC2 11/06/2007, PE 379.227, 2007.

[46] TU Delft, The Model of the Eco-costs/Value Ratio (EVR), 2012, online: http://www.ecocostsvalue.com/EVR/model/theory/subject/2-eco-costs.html (30.10.2016).

[47] Yip, T.L., Fu, X., Ng, A.K.J.: Transport logistics for sustainable growth at a new level, Proceedings of the International Forum on Shipping, Ports and Airports (IFSPA) 2012, C.Y. Tung International Centre for Maritime Studies, pp. 297308, Hong Kong, 2012, online: https://www.polyu.edu.hk/ $\mathrm{lms} / \mathrm{icms} /$ Proceedings/Proceedings $\% 20$ of $\% 20$ IFSPA $\% 20$ 2012.pdf (30.10.2016). 